Paideusis

\title{
Beyond Liberal Democracy: Diverse Educational Relations
}

\section{Barbara J. Thayer-Bacon}

Volume 15, Number 2, 2006

URI: https://id.erudit.org/iderudit/1072682ar

DOI: https://doi.org/10.7202/1072682ar

See table of contents

Publisher(s)

Canadian Philosophy of Education Society

ISSN

0838-4517 (print)

1916-0348 (digital)

Explore this journal

Cite this article

Thayer-Bacon, B. (2006). Beyond Liberal Democracy: Diverse Educational Relations. Paideusis, 15(2), 79-91. https://doi.org/10.7202/1072682ar
Article abstract

This essay offers a critical analysis of Locke's and Rousseau's basic assumptions upon which classical liberalism is built: rationalism, universalism, and individualism. I then describe an alternative starting place for democracy with a transactional view of individuals-in-relation-to-others. I then offer specific educational examples to help me sketch two themes that illustrate problems with classical liberalism and how a transactional democracy-always-in-the-making can help to solve these problems. (c) Barbara J. Thayer-Bacon, 2006

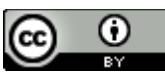

This document is protected by copyright law. Use of the services of Érudit (including reproduction) is subject to its terms and conditions, which can be viewed online.

https://apropos.erudit.org/en/users/policy-on-use/ 


\title{
Beyond Liberal Democracy: Diverse Educational Relations
}

\author{
BARBARA THAYER-BACON \\ University of Tennessee, USA
}

This essay offers a critical analysis of Locke's and Rousseau's basic assumptions upon which classical liberalism is built: rationalism, universalism, and individualism. I then describe an alternative starting place for democracy with a transactional view of individuals-in-relation-to-others. I then offer specific educational examples to help me sketch two themes that illustrate problems with classical liberalism and how a transactional democracy-always-in-the-making can help to solve these problems.

\section{Introduction}

I have a son in $9^{\text {th }}$ grade who is studying world history. ${ }^{1}$ Sam is up to chapter 22 in his book, "Enlightenment and Revolution," and in this chapter he is introduced to the ideas of key philosophers whose ideas helped contribute to revolutions in Europe and other parts of the world, including what would become the USA. We are having discussions about the ideas of Thomas Hobbes, John Locke, Voltaire, Baron de Montesquieu, Rousseau, and Beccaria. Sam has learned about differing views of human nature (Hobbes' view of humans as naturally selfish and wicked, Locke's view that humans can learn from experience and improve themselves by developing habits of good reasoning, and Rousseau's view of humans as naturally good who are corrupted by society). He has learned about various social contract theories, ideas concerning the separation of powers in a government, and the right to criminal justice. Most important, he has learned about the faith in science and in progress and how these led to the rise of individualism. "As people began to turn away from the church and royalty for guidance, they looked to themselves instead" (p. 556).

In discussing European history with Sam, I am reminded of the context of the times in which Locke (1632-1704) and Rousseau (1712-1778) wrote. Social institutions such as religion (the Catholic Church) and government (in the form of monarchies) had developed to such an extent that it seemed impossible to get out from under their yokes. People's lives were burdened with heavy taxes they had to pay for use of the land, as well as heavy contributions they had to make to the church. Those taxes and contributions were used to build the beautiful castles and cathedrals we tour today in Europe. Locke's social contract theory, where he argued that a government's power comes from the consent of the people, was a cry for change, for revolution. It was an argument that helped people see they can choose the type of government they have, and that if enough of them withhold their consent to their current

\footnotetext{
1 Roger Beck, Linda Black, Larry Krieger, Phillip Naylor, Dahia Ibo Shabaka, World History (Evanston, IL: McDougal Littell, Houghton Mifflin Co., 1999).

(C) Copyright 2006. The author, Barbara Thayer-Bacon, assigns to Paideusis the right of first publication and educational and nonprofit institutions a non-exclusive license to use this document for personal use and in courses of instruction provided that the article is used in full and this copyright statement is reproduced. Any other usage is probibited without the express permission of the author.
} 
government, they can change it. As Sam's book says, this idea of "consent by the people" serves as the foundation for modern democracy. Rousseau's idea that " $(\mathrm{m})$ an is born free, and everywhere he is in chains," is an argument that man is naturally good, free, and equal, but civilization corrupts that goodness. ${ }^{2}$ For Rousseau, governments are only good if freely formed and guided by the "general will" of the people. A social contract is an agreement among free individuals to create a society and a government. Once again, his theory was a cry for change and it led to revolutions.

When Sam and I discuss these ideas, we end up arguing. He just wants to learn the ideas so he can do well in his classroom discussion and on his next test. He knows I can help him as I am a philosopher of education and I teach a course on classical philosophical thought that has influenced American education. Locke's Some Thoughts Concerning Education and Rousseau's Emile are part of the curriculum in the course I teach. ${ }^{3}$ However, I am a feminist philosopher of education and I teach my classics course from a feminist perspective, where I bring women's voices into the conversation right from the beginning. I am currently working on a political theory that seeks to find a way to get democratic theory beyond the influence of Locke and Rousseau. I want to talk to Sam about what I find problematic about Locke's reason and Rousseau's human nature, and the individualism they both assume as their starting place. I want to bring a feminist critique to their work and suggest that while their assumptions may have helped men resist the power of the church and state at the time they were living, there are other routes they could have taken instead. These other routes would have helped them build a more inclusive democratic theory based on assumptions that would logically sustain democracies-always-in-the-making long into the future. I want to talk to him about how the very assumptions Locke and Rousseau offered - so revolutionary at the time-have actually been harmful in the long run in helping us have a chance of experiencing democracies someday. Sam doesn't want to hear all of this! He wants me to stay focused on the simple task he has of just learning what is in the book and nothing more. I comply for the evening because we are both tired and need to finish our discussion and get to bed. He's overloaded with homework, and the time is not right. I let him know I hope to continue the conversation with him when he is more willing.

So far Sam and I have not continued the conversation; however, the desire to discuss these issues is still strong within me. The current times in which we live are significantly different from the times in which Locke and Rousseau wrote. We live in a post-industrial, globally-influenced $21^{\text {st }}$ century where huge corporations have budgets larger than those of many countries, where individuals are wealthier than some countries, where religions hold significant sway in some parts of the world but not in others, where countries are joining together to form the European Union, where nations are working together to address global warming and other environmental issues (such as establishing the Kyoto Protocol), while the biggest contributor of greenhouse gases, the USA, refuses to participate. Surely these contextual differences - and I have only named a few-are enough to warrant a reexamination of classical liberalism. However, our post 9/11 context makes me feel an even stronger sense of urgency and a need to reexamine Locke's and Rousseau's assumptions for democracy.

As a U.S. citizen living in a country that presumes to serve as a model for how democracies should be, I worry about the role the USA currently plays on the global stage. Our leaders seem to think we can bring freedom to other people in far away countries (Afghanistan and Iraq) by using our military might to occupy their lands, and imprison and torture their citizens. These preemptive military strikes, we are told, will make the world safer from terrorism, but the death toll keeps climbing higher and higher as does the USA's debt and its alienation from other countries. I also worry about the current

\footnotetext{
2 Sam's textbook does not give a source for that quote by Rousseau, but I believe it is from Emile. My translation says: "Everything is good as it comes from the hands of the Maker of the world but degenerates once it gets into the hands of man." Selected readings of Emile, as found in Steven M. Cahn's The Philosophical Foundations of Education (New York: Harper and Row, Publishers, 1970): 155-176, 155.

${ }^{3}$ Selections of John Locke's Some Thoughts Concerning Education, and Jean Jacques Rousseau's Emile can be found in Cahn's The Philosophical Foundations of Education.
} 
domestic role the U.S. government chooses to play as the protector, relying on a logic of fear to protect its citizens from possible terrorist acts by eroding their civil rights. At the same time, the current presidential administration withdraws government support for domestic programs such as health care, education, and social security to pay the ever- increasing foreign-policy bill. We live in times when the very ideas Locke and Rousseau offered to support democratic theory are being used to undermine democracies. Surely this is a good time to reexamine Locke's and Rousseau's key assumptions and consider how we can get beyond liberalism as we know it today.

I want to make a case for the need to move beyond liberalism by first of all critiquing the assumptions that Locke and Rousseau used to develop their theories: the assumptions of rationalism, individualism, and universalism. I will offer alternative assumptions as starting places for developing a pluralistic, relational description of democracies-always-in-the-making. I will do this work with the help of feminist scholarship, as well as pragmatist and postmodern theories. As a cultural studies scholar, I also will turn to the many students and teachers whose schools I have visited over the last five years, to help me illustrate my ideas concerning democracies-always-in-the-making in their school contexts. The students I refer to are lower- income minority students, students of color whose voices are often not heard in conversations concerning democratic theory. The teachers I refer to teach their students in the USA on a Native American Reservation in the Southwest and in an urban Native American high school in the Midwest; they teach Mexican American students in Los Angeles, Chinese American students in San Francisco, and Japanese American and African American students in the Southeast. They tell me they feel disenfranchised from the USA's democracy. They will help me avoid universalism and give me a way to contextualize the ideas I have to offer, as I seek to include their insights and share their concerns.

\section{Classical Liberal Assumptions}

In fairness to Sam's education and what he is learning about world history, I must say that I am very impressed by what his world history text includes, in comparison to what I learned in high school, which was European history. Sam's text includes solid chapters on Asian history as well as African history, and the Americas (beyond the boundaries of the USA, to include Central and South America). There are even chapters on the Muslim world. His book includes discussions of contributions and developments in the arts as well as the sciences, and religious as well as philosophical influences. His text also includes an awareness of race, class, and gender issues, for it makes an effort to include diverse contributions to world history. For example, it includes women's contributions such as the discussion of Mary Wollstonecraft's ideas that is included in his chapter 22. I did not learn about Wollstonecraft until I was in graduate school and Jane Martin brought her to my attention. ${ }^{4} \mathrm{I}$ am also pleased to hear about the kinds of discussions Sam has in his class about the readings and to see the kinds of questions he is asked to write about for his essays.

Besides this textbook, Sam is also reading original historical documents and learning how to critique these. He is exposed to a variety of historical perspectives and is learning that there are a variety of ways to represent events that occur. He is learning a cultural studies kind of approach to world history, where power and social justice issues are very much part of the discussion, and that is all I could hope for as a parent who is a faculty member in a cultural studies of education program. Still, I would like for him to know about the work I am doing and what I hope to contribute to this conversation. While I am excited about the pluralistic perspectives and the diverse contributions he is exposed to, I am not happy that these ideas are not explored in more depth. I want to help him deepen

\footnotetext{
4 Jane Roland Martin, Reclaiming the Conversation (New Haven, CT: Yale University Press, 1985): Chapter 4, "Wollstonecraft's Daughters.
} 
his critical analysis. Sam reminds me in exasperation: "Mom, it is world history, covered in a one year course. There isn't time to go into much depth!" Sigh.

Let's look more closely at the assumptions Locke and Rousseau made, and consider criticisms that can be brought to bear on these assumptions today. A close read of Locke reminds us how much his political theory depends on human beings developing the ability to reason. Yet he turns his attention to advice on educating children because he does not believe children are born with the actual ability to reason, just with the potential to become reasonable. For Locke, all children start out as "blank slates" and they are very much influenced by their experiences. That is why it is so important to him that parents and teachers pay close attention to how they are educating children and what they do in their daily interactions with children. In order for children to grow up to be reasonable adults they must have reason modeled for them by their teachers and parents, and they must have plenty of opportunities to practice the use of reason themselves, so that they will develop the habits of good reason. From a positive perspective this means that humans can learn from their experiences and improve themselves, as Sam's book points out, but there is something troubling about Locke's theory that requires further discussion.

Locke's plan for teaching children to be reasonable is based on behavior modification; he advises never rewarding children with pleasure in terms of gifts or punishing them with pain such as corporeal punishment, but instead suggests using praise and the withdrawal of one's affections to shape the children into reasonable people. It is a plan that contradicts itself, one that doesn't really trust children to be reasonable unless they are shaped through adult manipulation, which is easy to do for adults can rely on children's feelings of affection for them and their dependence on them. How can Locke build a democratic theory that is based on the reasonable choices of consenting adults when he does not really trust that children will grow up to be reasonable adults unless they are very consistently raised by adults who have full responsibility for shaping them into who they will become? Locke's epistemological theory places children in vulnerable and passive, receptacle roles and it places adults in very powerful roles as the ones who write on the children's blank slates through the experiences they create for the children. ${ }^{5}$

The power that Locke places in the hands of adults is the power of social determinism and indoctrination. The parents and teachers have the power to shape the children into who they will become. This power is very similar to more recent social reproduction theories that argue that children are shaped into becoming factory workers/laborers, or leaders/professionals due to the social institutional experiences they have in their families, communities, and schools, for example. ${ }^{6}$ Not only does Locke's epistemological theory seem to undermine his aim of education-to help children develop the habits of reason through his recommended use of manipulation-but his position that people are shaped by their experiences, including the social forces they experience through their families, seems to undermine his assumption of individualism. First, though, let me establish that he does make an assumption of individualism.

We have already established that at the time that Locke was writing, social institutions had established their authority, in particular government (in the form of monarchies) and religion (in the form of the Catholic Church). Within familial institutions patriarchy was also strong, thus limiting any rights women had, and not recognizing children as having rights. Locke built his theory of liberalism on an assumption of individualism in order to undermine the authority of the church and the state. He argued that we are born as individuals, autonomous and free, and we decide whether to join up with

\footnotetext{
${ }^{5}$ Locke, Some Thoughts Concerning Education.

${ }^{6}$ See: Samuel Bowles and Herber Gintis, Schooling in Capitalist America (New York: Basic Books, 1977), and Henry A. Giroux, Idology, Culture, and the Process of Schooling (Philadelphia: Temple University Press, 1981). Giroux has an excellent essay that critiques reproductive theory, including his own, in "Theories of Reproduction and Resistance in the New Sociology of Education: A Critical Analysis," Harvard Educational Review, 53(3), August 1983, $257-293$.
} 
others or not to form associations. ${ }^{7}$ By starting from a position of individualism, Locke hoped to establish certain inalienable rights for all individuals that no social institution had the right to infringe upon. These rights could only be given up if by the individual's choice.

However, at the same time that Locke argued for individual freedom as a means to undermining the authority of the church and state, he did not seek to undermine the authority of another very powerful social institution: the family. In fact, it can be argued that he sought to increase the father's authority in the home. Locke increased the father's authority as head of the household, or at least underscored it, by making the father responsible for his son's education, to make sure he grew up to be a rational, autonomous adult. Thus we have two problems that Locke created for his own theory of individualism. First, Locke undermined his own assumption of autonomy and freedom by describing the important role the father must play in helping his son become autonomous by controlling the son's experiences, thereby admitting that we are not in fact born autonomous and free but must become so with the help of adults who shape us into the individuals we become. Second, he also made the grievous error of ignoring the role mothers play in their children's education and thereby placing all power and authority in the father's hands. How can he ever hope to develop a theory of liberalism that frees individuals from social institutional forces when his assumption of individualism is dependent on the strongest of social institutional forces, a patriarchal family?

Sam's book says that Locke's idea of "consent by the people" serves as the foundation for modern democracy. But now we realize that "the people" who were consenting for Locke were adult males who had grown up in households where their fathers used behavior modification, in the form of denial of approval and love, to shape their sons into thinking they were autonomous and free and able to make rational decisions for themselves. This foundation for modern democracy is contradictory and inconsistent, and seems to support a theory for social determinism more that a theory for democracy. At the same time, by attempting to describe people as starting out their lives autonomous and free, and positioning them as responsible for the choices they make in their lives in terms of the social institutions they construct, Locke allows governments off the hook from having any responsibility in helping their citizens grow and develop to their full potential.

Locke was worried about making sure governments can only be strong enough to protect individual rights, but not so powerful that they can infringe on individual rights. He hoped to establish democratic governments that offered individuals the service of safeguard and protection, while at the same time keeping that service in check to make sure governments do not infringe on individual rights any more than is necessary to protect us. Locke describes a relationship between individuals and their government that is based on distrust and suspicion; it is one where the individual must always be on the watch to make sure the government is powerful enough to protect individual rights, but not so powerful that it takes away individual rights.

Unfortunately, as we can see today in the USA, Locke's theory leads to a situation where governments can wash their hands of any responsibility in helping people develop into adult citizens, for it is now up to the individual, and the individual's patriarchal family, to make those choices. The efforts of the current president of the U.S. to privatize many social services such as social security, health insurance, and education fit logically within Locke's political philosophy. The moves to privatization protect the classical liberal values of individual freedom and choice and the liberal desire to keep governments contained and out of our private lives. At the same time, the current U.S. presidential administration models Locke's classical liberal values by taking seriously its role as protector of its citizens through the use of its military might to invade other countries that are running terrorist training camps and potentially developing weapons of mass destruction. In the name of protecting its citizens, the USA has invaded two other countries, killing many innocent citizens in these countries, has removed their leaders from office by force, and has put citizens in prisons without any recognition of

7 John Locke, The Second Treatise on Government (Cambridge: Cambridge University Press, 1960), originally published in 1823. 
criminal rights. The battle cry is "Freedom is on the march!" Freedom for whom, we need to ask, and at what expense to democratic theory? With a logic that undermines and contradicts itself, no wonder we are still struggling to develop democracies today!

What about Rousseau: does he fare any better than Locke? Do his assumptions help to support a democratic theory? Rousseau bases his democratic theory on an assumption of human nature as naturally good that becomes corrupted by society. This assumption of goodness is certainly contrary to the Christian belief in original sin that was prevalent at the time of Rousseau's writing. This idea alone was probably enough to get him in trouble with church leaders and force him to have to leave his country. Rousseau hoped to get people out from under the powerful sway of social institutions (such as the church) by declaring not only our natural goodness but also our natural independence from society. He describes individuals as beginning their lives free and unencumbered, and then losing their freedom as they join up with others to form societies. Unfortunately, "nature" or "human nature" are concepts that are hopelessly vague, as Steven Cahn points out in his description of Rousseau's contribution to educational philosophy. ${ }^{8}$ Nature is a concept that cannot be defended-as anything we do can be attributed to human nature, and therefore any policy we adopt based on "human nature" can be defended on the grounds that it is "natural." An argument for democracies can be supported by relying on a concept of human nature; but so can an argument for any other form of government, including fascism.

From a feminist perspective, the easiest way to demonstrate how far one can stray with a democratic social/political policy based on "human nature" is to look at Rousseau's own description in Emile. When he describes Èmile's education as a young child, Ėmile is free to roam and learn his lessons from nature. Ėmile is allowed to explore the world and follow his own interests, while his own private tutor goes along with him facilitating Ėmile's education. There are many lovely passages on the need to be humane with children and love them, allowing them to be children and not treating them like miniature adults. Rousseau does not embrace Locke's advice to reason with children, for he thinks children are not yet capable of reason. Instead, he wants us to treat children in age-appropriate ways, and let nature teach children the lessons they need to learn. The tutor is not to claim any authority over the pupil; rather, the tutor is to let the child learn through direct experiences, as the child feels "the heavy yoke which nature imposes on man." 9

However, in the last chapter of Emile, in which Rousseau describes the ideal education for girls through his description of Sophie's education, we discover the yoke of social institutions that Rousseau recommends be placed on little girls' educations, so that they will grow up to be proper wives for Rousseau's free, self-made men, like Ėmile. Ėmile may be allowed to grow up free and exploring the world around him, with no social norms imposed upon him and no need to take other people's needs into consideration, but not Sophie. She is to remain in the home and to be taught to enjoy such confinement. The entire focus of her education is to be about learning how to care for the home and please her family. She is to learn domestic skills, such as how to cook and clean and darn and knit, as well as how to be charming in her mannerisms, and faithful in her relationships.

Interestingly enough, the chapter on Sophie's education is the one most often left off in various selected editions of Emile, as Martin points out in her Reclaiming the Conversation. ${ }^{10}$ Cahn's selection of Emile is no exception, also neglecting this important chapter. Yet, it is impossible to have a complete understanding of Rousseau's educational philosophy without his final chapter on Sophie's education. We cannot appreciate the full impact of the contradictions embedded in his social/political theory without it, either. While he was able to throw off the yokes of church and state with his claim of human nature being naturally good and independent, Rousseau reasserts the social institution of patriarchal family through his description of Sophie's education. Apparently, socially constructed gendered

\footnotetext{
${ }^{8}$ Cahn, The Philosophical Foundations of Education, 153-154.

${ }^{9}$ Rousseau, Emile, 162.

10 Martin, Reclaiming the Conversation, Chapter 3.
} 
behaviors taught to little girls are perfectly "natural" and should be taught to them, while socially constructed behaviors of any kind taught to little boys are not "natural" and should not be imposed upon them. So much for ridding us of the yokes of society! And now we can see the problem with building a democratic theory on an assumption of "what is natural." Not only is it a vague concept that is impossible to define and defend, but as philosophers it is impossible for us to ever completely remove ourselves from our own situatedness as fallible human beings embedded within a particular time and place, acculturated to "see" as "natural" and "normal" what our social institutions have taught us. We can never completely detach ourselves from our own embeddedness to gain a universal, God's eye view of the world in which we live. Always, we will only be able to understand our world from within our limited, partial views. For both Locke and Rousseau, theirs were worlds that were not only elitist (their educational plans were aimed for wealthy children whose families could afford to hire tutors), they were also deeply sexist, and no attempt made by either of them to include girls and women in their descriptions of rational, autonomous individuals, those being the basic assumptions upon which they built classical liberalism. From a feminist perspective, Locke and Rousseau can never lead us to democracy.

We have found that Rousseau does not fare any better than Locke in offering us assumptions that can support a democratic theory. Rousseau's free and unencumbered individual is a myth, but as long we try to cling to that myth we find ourselves again in a situation where governments can wash their hands of any responsibility in helping people develop into adult citizens, for it is now up to the individual, and the individual's patriarchal family, to make those choices. If individuals are not able to afford good education for their children, or good health care plans, or save for their own retirements so their children will not be overburdened with having to take care of them in old age, they have no one but themselves to blame. Governments that offer their citizens safety nets to protect them from financial ruin are governments that have grown too large and have too much power and sway over our lives. Again we find that the efforts of the current president of the U.S.s to privatize many social services such as social security, health insurance, and education fit logically within Rousseau's political philosophy, as well as Locke's. That the USA currently spends more money paying for the care of its jailed criminals (a significant number of people!) than it does for prenatal care, well-baby clinics, early childhood education and K-12 education for the well-being of its future citizens, stands as hard evidence of what happens to democracies that begin with a social political theory that assumes individuals are autonomous and free. ${ }^{11}$

\section{Assumptions for Democracies-Always-in-the-Making}

I want to propose another route that Locke and Rousseau could have taken to position us for the possibility of democracies-someday, for democracies are ideals for which we can aim, not realities we can ever fully achieve. My starting place is not with the reasoning capacities we achieve through indoctrination and manipulation, nor with a human nature we cannot define or defend. Most importantly, I do not begin with an assumption of individualism, that each of us begins our lives autonomous and free. Both Locke and Rousseau turned to individualism as the way to get out from under the yoke of social institutions such as the church and the state. But their individualism was a false illusion right from the start, for they ignored the powerful influence of family that all children experience from birth on. In fact, I want to argue that children begin to experience a familial influence even before they are born, for their mothers who bear them live within the context of social institutions that affect their mothers' well-being, and thus theirs, even while the mothers carry them in their wombs.

\footnotetext{
11 Jonathan Kozol gives powerful statistics on the money spent for prison inmates versus money spent on
} educating our children in the USA. Jonathan Kozol, Savage Inequalities (New York: Crown Books, 1991). 
In letting go of individualism, I do not want to embrace communitarianism either, which starts with the social community as the base from which we derive individuals, thus placing individuals always within the danger of social determinism. ${ }^{12}$ Liberalism and communitarianism seem to be logically exclusive of each other, presenting themselves in a way where one must choose either one or the other. I want to argue for a both/and logical approach that suggests we can learn from the strengths and weaknesses of individualism and communitarianism in developing a democratic theory. I begin with a transactional description of selves-in-relation-with-others, that describes individuals as influenced and affected by others, including our natural world; it is a relationship that works both ways, and all are changed as a result.

This transactional relational view of democracy does not assume universality. It is located in the contingent, local, everyday world of diverse people and their values and beliefs. It is located in a world of specific material needs such as shelter, food, jobs, healthcare and childcare, as well as a world of social, psychological, and spiritual needs. It seeks to address real people and their concerns in terms of their specificity and situatedness, as well as in terms of their diversity and plurality. It does not seek to homogenize and whitewash distinctions and unique qualities, but at the same time it aims to address people's commonalities across their differences. This relational democratic theory is not only pluralistic in terms of embracing cultural diversity, it is also pluralistic in that it does not argue that there is one universal Answer or Truth upon which in the end of time we will all agree. Rather, it is a theory that suggests there are many answers and truths and in the end we will still have a variety of ways of explaining our world and our experiences, relying on a variety of tools to help us in our descriptions. In the end of time, we will still be discussing and debating, meditating and chanting, singing and dancing, as we consider new possibilities. This theory does not suggest that we can hope to solve all of our problems by some special method such as Language Analysis, Historical Analysis, Phenomenology, Hermeneutics, or the Scientific Method with the use of an important tool such as Reason or Intuition. Instead, it recognizes that we use a variety of tools to help us solve our problems, and that they all have important roles to play in our inquiring processes. I am presenting a democratic theory-always-in-themaking that is never complete and finished. It is a comprehensive theory in that it argues for the need to inform all kinds of social institutions in order for such a democracy to thrive. These social institutions include our families, churches, work places, and schools—not just political forms of government-for social institutions in all their forms exert power over individuals at the same time that they generate power due to individual contributions.

John Dewey is one of my key sources for a relational view of democracies-always-in-the-making with his concept of transaction. Dewey recognizes we start out as members of communities, in associated living, and that our first community is our family, where we are nurtured, and where we experience face-to-face relationships. He begins his classic work, Democracy and Education with a discussion of social communities, and how individuals develop out of those communities. ${ }^{13}$ In many of his writings we can find Dewey discussing infants and their relationships to their mothers as well as their extended families. Contrary to classical liberal philosophers, Dewey does not treat individuals as if they sprout out of the ground without mothers who nurse them and fathers who bathe them. He does

\footnotetext{
12 Examples of communitarian theories include: Benjamin Barber, Strong Democracy (Berkeley: University of California Press, 1984), Judith Green, Deep Democracy (Lanham, MR: Rowman \& Littlefield Publishers, Inc., 1999), and Michael Walzer, Spheres of Justice (New York, Basic Books, 1983). An analysis of communitarianism is not developed in this paper, as it is beyond its scope. However, an example of criticism of communitarian theories can be found in Laclau and Mouffe's work, where they caution that communitarians represent the "common good" as derived from political debate that is peaceful and benevolent conversation and harmonious dialogue, thus ignoring the ubiquity of domination and resistance in all discursive situations. Ernest Laclau, and Chantal Mouffe, Hegemony and Socialist Strategy: Towards a Radical Democratic Politics, Winston Moore and Paul Cammack (Trans.) (Great Britain: The Thetford Press Ltd., 1985).

${ }^{13}$ Dewey, Democracy and Education (New York: The Free Press, MacMillan, 1996/1916).
} 
not seem to ever lose sight of the fact that we all begin our lives in someone else's loving arms. Dewey developed a sense of self that begins in-relation-with-others, a social self that develops and grows to become more autonomous and rational as we continue to interact with others. Many have written about the influence Dewey's friend and colleague, George H. Mead, a philosopher and sociologist, had on his social concept of self. ${ }^{14}$ But I think Dewey made a significant amendment to Mead's social concept of the self by recognizing that young children, even infants, make significant impacts on social communities, too: it is not just a one-way influence. Mead's individual tends to be subsumed by the generalized other, whereas Dewey's individual actively interacts with and changes society. ${ }^{15}$

It is not until late in Dewey's career, in his work co-authored with Arthur Bentley, Knowing and the Known, that he introduces the term transactional, but one can find the seeds of this idea in many of his earlier writings, including Democracy and Education. ${ }^{16}$ Earlier Dewey used the term "interaction" to describe relationships that affect each other, but later he amended the term to "transaction" because he realized that individuals can interact with each other without necessarily being affected in significant ways, like billiard balls that hit and bounce off each other on a pool table but still maintain their original form. For Dewey, selves interact with others in ways where both are changed as a result, and thus their relationship is more accurately described as a "transaction." Communities help to shape the individual into whom s/he becomes, but individual selves, as immature young members of the community, help to shape and change the community, as well, due to their immaturity--which allows them to be flexible, open, adaptive, and growing.

Other sources for beginning with an assumption of transactional relationships come from feminist scholarship in the 1980's that strove to describe how selves begin their lives in-relation-withothers, in particular in relation with those who care for them. While there are many problems with that earlier work, still, Nel Noddings, Sara Ruddick, and Jane Flax in particular are three feminist scholars who reminded us that children do not begin their lives as individuals, they become individuals through their relationships with their care providers. ${ }^{17}$ As Noddings describes the self:

I am not naturally alone. I am naturally in relation from which I derive nourishment and guidance. When I am alone, either because I detach myself or because circumstances have wrenched me free, I seek first and most naturally to reestablish my relatedness. My very individuality is defined in a set of relations. ${ }^{18}$

\footnotetext{
${ }^{14}$ Gary Cook, George Herbert Mead (Champaign, IL: University of Illinois Press, 1993); Jim Garrison, "Deweyan Pragmatism and the Epistemology of Contemporary Social Constructivism," American Educational Research Journal, 32, no. 4 (1995, Winter): 716-740; and Charlene Haddock Seigfried, Pragmatism and Feminism (Chicago: University of Chicago Press, 1996). ${ }_{15}$ George H. Mead, Mind, Self, and Society (C. W. Morris, Ed.) (Chicago, IL: University of Chicago Press, 1934). I discuss the distinctions between Mead's social self and Dewey's transactional self in more depth in Chapter 5 of Relational "(e)pistemologies” (New York: Peter Lang Inc., 2003).

${ }^{16}$ John Dewey and Arthur Bentley, Knowing and the Known (Boston, MA: Beason Press, 1960/1949).

17 Jane Flax, "Political Philosophy and the Patriarchal Unconscious: A Psychoanalytic Perspective on Epistemology and Metaphysics," in Discovering Reality, eds. Sandra Harding and M. B. Hintikka (Dordrecht, Boston, London: D. Reidel Publishing Co., 1983), 245-281; Nel Noddings, Caring (Berkeley, CA: University of California Press, 1984); Sara Ruddick, Maternal Thinking (Boston: Beacon Press, 1989). I address criticisms to their work at length as well as their responses in Chapter 4 of Relational "(e)pistemologies." I do not mean to suggest that these are the only scholars contributing to the concept of relationality, I have written an entire book exploring the concept just within an (e)pistemological framework, discussing many scholars contributions, and there are even more contributions if the topic of relationality is approached from an ontological direction. See: Thayer-Bacon, Relational "(e)pistemologies."

18 Noddings, Caring, 51.
} 
For Noddings, we begin our lives in relation; it is an ontological basic for us. She establishes our relationality through her discussion of caring relationships-the one-caring and the one-cared-forextending these relationships beyond the boundaries of home and parents to include schools and teachers. Ruddick helps to establish our fundamental relationality through her exploration of the maternal relationship with the child as she helps us understand that a child's spirit unfolds through the intimate relationship with another. Ruddick's focus is predominantly from the perspective of the "mother," the "person who takes on responsibility for children's lives and for whom providing child care is a significant part of her or his working life." 19 She looks closely at demands that arise with mothering, demands of protecting the child from harm, helping the child to grow and flourish, and preparing the child to be socially acceptable in the society in which the mother and child reside. Flax makes the case for our fundamental relationality from the perspective of the child, relying on psychoanalytic theory to help us understand how we are literally constituted by the relationships in which we participate. For Flax, the psychological birth of the human infant takes around three years, and this complex process can only occur in and through social relations, in particular social relations with the infant's caregivers. ${ }^{20}$ For these feminist scholars, the relationality they describe is one of mutual interdependence and independence, it is a relationship of reciprocity that Rousseau was not able to imagine, for his natural man was left with a choice between isolation or total engulfment.

Postmodern feminists such as Luce Irigaray and Judith Butler offer powerful criticisms of Enlightenment descriptions of the 'self' as following a masculine model: the mentalist, de-eroticized, masterful, and oppositional self." 21 Pychoanalytic theory is criticized by them for its tendency to describe all selves as the same, "the self," with sameness imposed at the level of the unconscious, in terms of self-development. In psychoanalytic theory, the infant develops a core identity that is either male or female, which effectively closes off and limits the gender experience. Both Irigaray and Butler have worked to destabilize the category of woman/man and remind us that the very concept of subject (self) is a male concept that positions woman in the othered role. We certainly see their point illustrated clearly in Locke's and Rousseau's concepts of the subject, as described above. Sophie is in the othered role in Emile. Irigaray and Butler both push us to move beyond the Enlightenment project, with its view of the self as an individual that can turn to reason for liberation. They seek to heal the split between the mind/body and to push for a loss of reification of gender relations. Butler and Irigaray bring contingency to our concepts of 'self,' 'subject,' 'individual,' as they abandon the Enlightenment concept of 'self" as "fictive."

Total abandonment of the concept of 'self' leads to problems, though, as Flax points out in response to criticisms of her work. ${ }^{22}$ She worries that postmodern deconstructions of the self can become a new strategy for evading, denying, or repressing the importance of early childhood experiences. ${ }^{23}$ Flax argues that it is possible to recognize repressive social forces to which we are all exposed, and admit that our selves are multifarious, contingent, and fractured due to these repressive forces, and still maintain some sense of what she calls a "core identity." Without a core identity we risk mental illness, psychosis. My research of Native American struggles with loss of core identities due to their experiences of 500 years of genocide agrees with Flax's position that we cannot ignore the vital importance of a sense of self. Native Americans such as the Navajos have suffered the impact of loss of identity by having the social fabric of their tribes pulled apart by U.S. governmental policies. The destructive results for them are high alcohol and drug abuse levels as well as high suicide levels, to name

${ }^{19}$ Ruddick, Maternal Thinking, 40.

${ }^{20}$ Flax, "Political Philosophy and the Patriarchal Unconscious," 250-254.

${ }^{21}$ Luce Irigaray, Speculum of the Other Woman (Ithaca, NY: Cornell University Press, 1974/1985), Judith Butler, Gender Trouble (New York: Routledge, 1990).

22 Jane Flax, Thinking Fragments (Berkeley, CA: University of California Press, 1990).

${ }^{23}$ Ibid, 232. 
but a couple of examples. However, Native American holistic spiritual beliefs can show us the way out of such dangerous and dichotomous thinking, with their descriptions of the self in terms of relationality, as selves-in-relation-with-others. For every Native American tribe that I am aware of, human beings are described as beings who live their lives not only in relation with each other, but also in relation with their animal brothers and sisters and the natural world that surrounds them. Their relational ontology extends beyond the boundaries of human relations to include Nature, and I capitalize 'Nature' on purpose to underscore its spiritual significance as a sacred being for Native Americans. ${ }^{24}$

Native Americans offer vivid examples of what happens when cultural groups are subjected to the colonizing will of majority social norms and standards very different from their own. Those norms and standards act like poison upon the individual and their social group. The opportunity to develop a sense of shared identity with others from one's social group is destroyed. With that destruction comes self-hatred. As I have learned from my research, Native American tribes such as the Navajo do not have the luxury of worrying about themselves and their individual needs, and forgetting about how their lives are connected to others around them. Nor do they have the luxury of forgetting about material needs and diversity issues, as minorities living in a colonizing world that has practiced genocide on them. That tribes in the USA such as the Navajo still exist and are growing in population is a vivid statement of incredible perseverance, adaptation, and strength. Their schools, like the Diné Primary School I visited, are important symbols of possibility and hope, even as the schools continue to fight the effects of acculturation by White Man's culture. ${ }^{25}$

A transactional view of individuals-in-relation-to-others helps us underscore the importance of sharing identities in democracies that are always-in-the-making. It reminds us how connected we are to each other, how much we influence and affect each other, and helps us understand how different and disconnected we are, reminding us that we are strangers to ourselves and to each other. A transactional view of individuals-in-relation-to-others offers a both/and logic that does not dismiss individualism or collectivism, but offers a way to neutralize their poisonous effects on each other. It offers us a way of avoiding the naively selfish and self-centered, hedonistic view of classical liberalism as well as a way of taking seriously the liberal fears of social determinism that a collective, social perspective represents. Fears of colonization and oppression by others are majority fears; those colonized are already living in a state of oppression, fighting for their lives, fighting for sovereignty as a way to maintain shared identities with their clan, upon which their chances of avoiding self-hatred depend.

The staff and students at La Escuela, a school in central Mexico I visited, have much to teach us as well. La Escuela is an award-winning educational program that has been helping over 2,500 children and adults from indigenous communities in a central state of Mexico for twenty years-people unable to afford attending public schools. They say in their publications that they seek to empower disadvantaged children and youth who live in remote areas, and create a sense of cultural belonging and commitment toward their own communities, so families won't leave the area and migrate to the USA. I learned from my observations at the school that the staff accomplishes these goals by treating the children as if they share responsibility in each other's well being; the students assume that responsibility and do monitor themselves, as well as each other. La Escuela is a school where students learn how to be active, participating citizens with shared responsibilities. We can learn from the founders and staff at $L a$ Escuela that students only feel a sense of shared responsibility when we treat them with respect and

${ }^{24}$ Dee Brown, Bury my Heart at Wounded Knee (NY: Bantam Books, 1971); Eduardo Duran and Bonnie Duran, Native American Postcolonial Psychology (Albany, NY: State University of New York Press, 1995); Deborah Davis Jackson, " 'This hole in out heart' The urban-raised generation and the legacy of silence," in American Indians and the Urban Experience, pp. 189-206; Richard Morris, "Educating Savages," Quarterly Journal of Speech 83 (1997): 152171; Jon Reyhner (Ed.), Teaching American Indian Students (Norman, OK: University of Oklahoma Press, 1992).

25 All names have been changed in the text to protect the identity of the schools and the participants in the school communities. 
dignity, and view them as important and valued contributors to the school community. By creating a place where students' contributions are sought and greatly valued, we teach students that they can contribute to their larger society and actively participate in a democratic society-always-in-the-making. We help them learn how to open up an inclusive space for shared responsibilities with the hope of making their/our world a more caring and just place in which to live. The staff of La Escuela have discovered a path to democracy that does not emphasize individualism at the expense of community, or vice versa. They have found a relational path that recognizes the transactional qualities of individuals in relation to others. La Escuela serves as an excellent example of a form of democracy that is always-inthe-making, a form of democracy that moves beyond Locke's and Rousseau's liberal democracy with the help of a transactional view of social relations.

\section{Conclusion}

Classical liberal democratic seeds have been sown in all the countries colonized by England and France in particular, and now the USA by extension, for the USA was originally colonized and influenced by these same values. The resulting values of classical liberalism can be found expressed in school designs and structures throughout the world, as well as in other social institutions, such as various forms of government. I began this essay with a critical analysis of Locke's and Rousseau's basic assumptions upon which classical liberalism is built: rationalism, universalism, and individualism. I then described an alternative starting place with a transactional view of individuals-in-relation-to-others. Next I turned to specific educational examples to help me sketch two themes that illustrate problems with classical liberalism and how a transactional democracy-always-in-the-making can help to solve these problems.

I learned from the teachers and students at Diné Primary School that the issue of acculturation by a majority culture that assumes a strong individualistic perspective is a very important one to address. When one comes from a collective cultural perspective, as Navajos do, it is impossible to digest a heavy dose of classical liberal individualism without becoming sick. The sickness can come in forms that seem benign, but they have proven to be lethal to the psyche of Native Americans, individually and collectively. I learned from the teachers and students at La Escuela that a relational focus teaches us to pay attention to our priorities and values, and to place people at the top of our list, ahead of technology, punctuality, and control. We begin to pay attention to relationality by noticing how we create spaces and opportunities for students to be able to participate in the responsibilities of, and help to make decisions for, concerns for the future of their school. Because the classical liberal view of democracy treats individuals as if they are separate from others, and views others as impeding on and slowing down individual progress, learning how to help others and work together collaboratively to achieve more caring and just lives is not something taught readily in the American schools I have observed.

What I seek to offer in this paper is the beginnings of a relational, pluralistic democratic theory that is based on a transactional view of individuals-in-relation-to-others, not individualism; that is based on contingency, locality, and specificity, as well as commonality, not universality; that is based on a plurality of truths and a multiplicity of tools available for our use in helping us determine the best answers and solutions we can co-construct, given our fallibility and our diversity, not rationalism; that seeks to address concerns of power, access, and material need. I think this transactional view of individuals-in-relation-to-others offers a powerful antidote to classical liberals' individualism, and gives us a way to imagine that we can work toward a democracy that is welcoming to all our children, a democracy-always-in-the-making that is never finished or complete.

I am pleased to know that Sam has come with me on this research journey, traveling with me to foreign countries to observe in their schools and listening to me share the stories of classrooms in the USA where I have spent time. He has stayed in the homes of kind hosts and hostesses to us and he has had the opportunity to play host in his own home to them as well, for the people who have opened up their schools and homes to us have become good friends. This is why I am not worried that Sam and I 
haven't had the chance to finish our conversation that his chapter 22 triggered. I know he will be with me when school is out and homework and tests are completed, as we travel to China and spend time in their schools this summer. When the year of studying world history is over, we will still be together and have plenty of time to talk. ${ }^{26}$

\section{About the Author}

Barbara Thayer-Bacon is a professor in the program of Cultural Studies in Education, University of Tennessee. Her primary areas of scholarship as a philosopher of education are feminist theory and pedagogy, pragmatism, and cultural studies in education.

${ }^{26}$ I have written about the schools in my C.A.R.E. research project in much more depth than room allows here. The book that will result from this project is tentatively titled, Beyond Liberal Democracy: Diverse Educational Relations. 